粘膜下層（sm）浸潤胃癌の臨床病理学的検討

\begin{tabular}{|c|c|c|c|c|c|}
\hline & & 群馬大学 & 2 外科（主 & 泉雄 & 勝教授） \\
\hline 宮 & 本 & 幸 & 大 和 田 & 進 & 棚 橋 美 \\
\hline 川 & 井 & 忠 和 & 泉 & 勝 & \\
\hline
\end{tabular}

$\mathrm{sm}$ 胃癌の粘莫下層への癌浸潤程度を以下の如く 4 群に分類した. $\mathrm{sm}_{0}$ ：潰瘍疾痕上の 再生上皮に癌がみられるがその他は㫊である. $\mathrm{sm}_{1}$ ：粘膜筋板を破って粘膜下首にわ ずかに漫潤しているが，大部分は を除くすの. $\mathrm{sm}_{3}$ ：筋䅉に接する浸潤があり大部分が粘膜下層へ浸潤している。

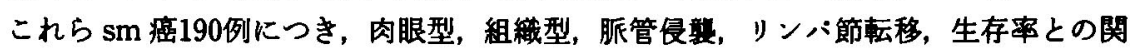
保について検討した結果, sm 浸潤程度が高度になると, 隆起型, 隆起十陥凹型の頛度が 高く、リンバ節転移率, 脈管内侵襲陽性率む高くなり，10年生存率が低下した。

来引用語：早期胃癌, sm 胃癌遠隔成績

\section{I. 緒 砉}

近年、胃診断学の進歩ならびに幅広い集団検診によ り，多くの早期胃癌が発見されている。教室に批いて も第 1 内科, 群馬県対ガン協会の協力により早期胃癌 の実数ならびに，全胃癌中の比率は次第に増加してい る。早期胃癌の治療成綪は極めて良好である。しかし 早期胃癌のなかでも，粘膜層 $(\mathrm{m})$ の癌と粘膜下層 $(\mathrm{sm})$ の癌とでは，生存率に差があるといわれ，その予後を 左右する因子としてリンバ節転移，腹管侵熋等があげ られる.そこてこの sm の組織学的浸潤程度を 4 段階 に分けて肉眼型, 組織型, 脈管曼㜔、リンバ節転移, 生存率について検討した。

\section{II. 対象およU゙方法}

昭和32年より昭和60年 5 月までの早期胃癌切除例 358例の5ち粘膜下層浸潤癌 (以下 $\mathrm{sm}$ 癌とする) 190 例 をもちいた，sm癌の粘膜下層への癌漫潤程度を連続 切片を作成，H.E染色をおこない，組織学的に 4 群に

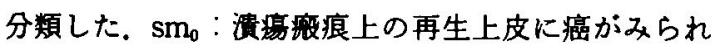
るか，その他は粘膜内癌 (以下 $\mathrm{m}$ 癌とする)である(写 真 1) $\mathrm{sm}_{1}$ : 粘膜筋板を破って粘膜下層にわずかに漫 潤しているが，大部分はm癌である (写真 2). $\mathrm{sm}_{2}$ ： 粘膜下層への浸潤が比較的多く, $\mathrm{sm}_{3}$ を除くむの(军基 3). $\mathrm{sm}_{3}$ ：筋層に接する浸潤があり，大部分が粘膜下 層へ浸潤している（写事4）．それぞれの症例は $\mathrm{sm}_{0}$ ； 7 例, $\mathrm{sm}_{1} ; 69$ 例, $\mathrm{sm}_{2} ; 71$ 例, $\mathrm{sm}_{3} ; 43$ 例である。 こ

昭和61年12月 6 日受付 62 年 2 月 24 日採用

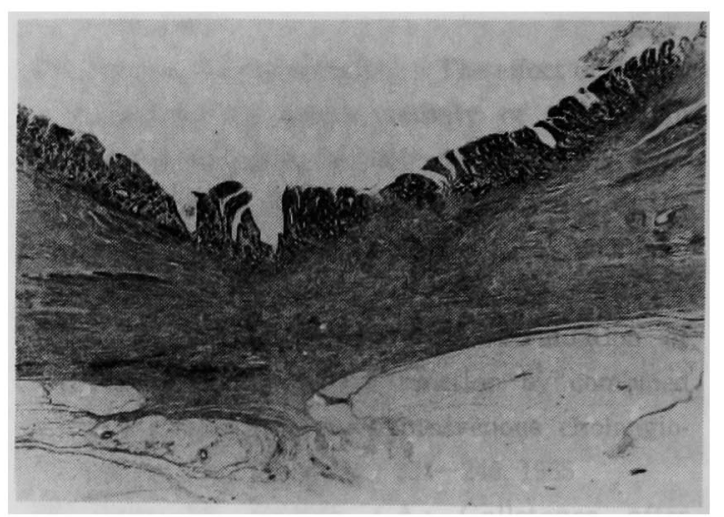

写真 1 演場痕上の再生上皮に疝がみられるが，そ の他は的である $\left(\mathrm{sm}_{0}\right)$.

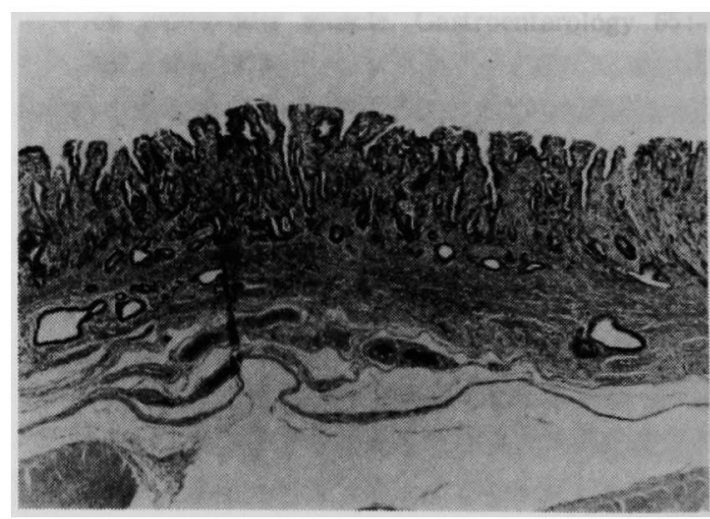

写真 2 粘膜筋板を破って粘膜下首にわずかに浸注し ている $\left(\mathrm{sm}_{1}\right)$. 


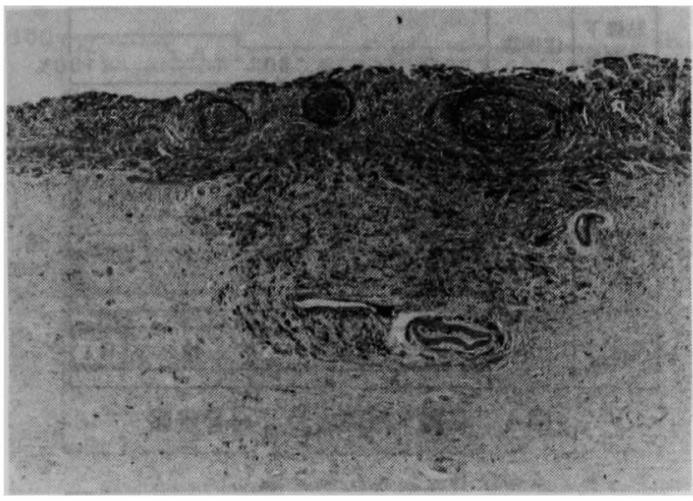

写真 3 粘膜下層への漫润が比较的多い $\left(\mathrm{sm}_{2}\right)$.

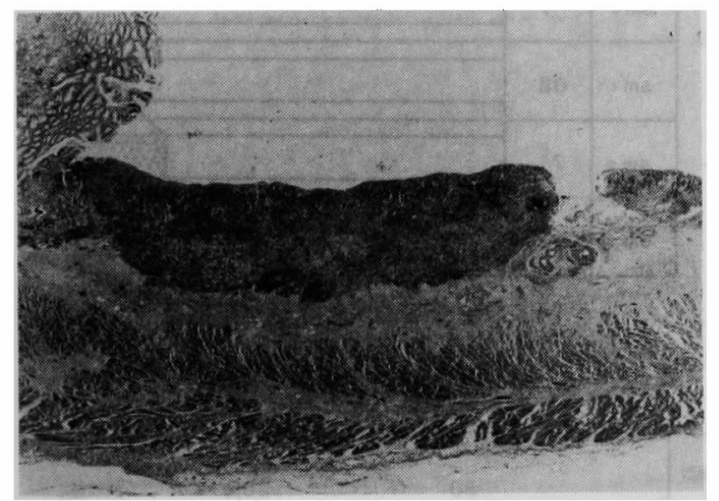

写重 4 筋居に接する漫潤があり大部分が粘膜下浸洞 である $\left(\mathrm{sm}_{\mathbf{s}}\right)$.

れらの症例について肉眼型, 組織型, リンパ筋転移, そして生存率につき検討した。

\section{III. 成 縝}

1. $\mathrm{sm}$ 漫潤程度と肉眼型との関係

肉眼型が判明している187例のらち $\mathrm{sm}_{0} \sim \mathrm{sm}_{2}$ にお。 いては IIc 型の宿凹型が60 70\%と多い. 一方 $\mathrm{sm}_{3}$ に 捻いては I 型, Ila 型の隆起型が多く, IIa + IIc 型など の隆起十陥凹型を加えると半数以上となり, IIc は减少 している(图 1).

2. $\mathrm{sm}$ 浸潤程度と組織型との関係

$\mathrm{sm}_{0}$ と $\mathrm{sm}_{1}$ に括いては分化型である管状腺癌（tub） か50 70\%である。一方 $\mathrm{sm}_{2}$ においては管状腺癌が減 少し，低分化腺癌（por）か50\%となっている. $\mathrm{sm}_{3}$ に おいては管状腺癌が減少し, 低分化腺癌と印環細胞癌 で半数をしめている(図2).

3. $\mathrm{sm}$ 浸潤程度と脈管内侵襲との関係

A) 静脈侵襲（v）について

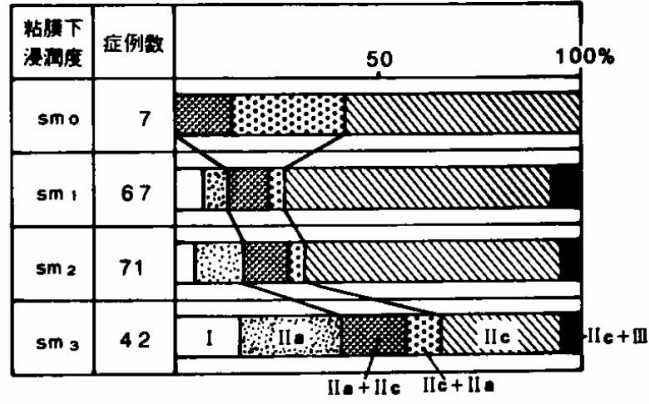

图 1 粘膜下浸洞度と肉眼分類

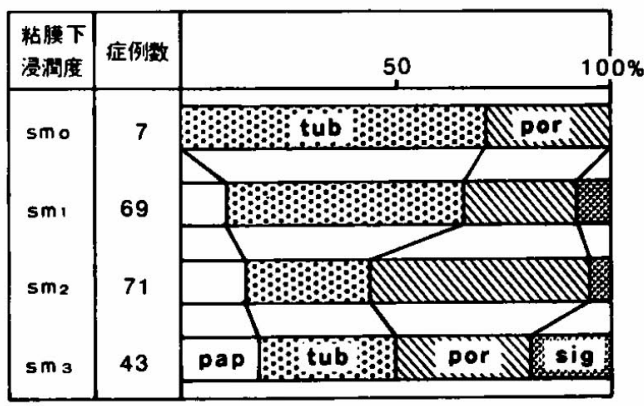

图 2 粘膜下漫潤度と組織学分類

\begin{tabular}{|c|c|c|c|}
\hline $\begin{array}{c}\text { 肉眼分類 } \\
\text { (型) }\end{array}$ & 症例数 & 50 & \\
\hline 隆 起 & 38 & vo & (2) \\
\hline $\begin{array}{l}\text { 隆起 } \\
\quad+\text { 宿凹 }\end{array}$ & 34 & & \\
\hline 陥 凹 & 115 & & \\
\hline
\end{tabular}

図 3 肉眼分類と繁脈侵蹋

陽性率は $\mathrm{sm}_{1} ; 8 \%, \mathrm{sm}_{2} ; 17 \%, \mathrm{sm}_{3} ; 30 \%$ で浸潤 が高度になると高くなっている。 また $\mathrm{sm}_{3}$ では $\mathrm{v}_{3}$ の頻 度す高くなっている(図了）。

B）リンパ管侵裂 (ly) について

陽性率は $\mathrm{sm}_{1} ; 23 \%, \mathrm{sm}_{2} ; 50 \%, \mathrm{sm}_{3} ; 72 \%$ で漫潤 が高度になると，高くなっている. そして $\mathrm{sm}_{3} て ゙ は \mathrm{ly}_{2}$, $\mathrm{ly}_{3}$ の頻度も高くなっている（図4）.

4. $\mathrm{sm}$ 漫潤程度とリンバ節転移 $(\mathrm{n})$ との関係 転移陽性率は $\mathrm{sm}_{1} ; 12 \%, \mathrm{sm}_{2} ; 21 \%, \mathrm{sm}_{3} ; 52 \%$ で 浸潤が高度になると高くなっている。 そして $\mathrm{sm}_{3}$ の $\mathrm{n}_{2}$ （+）は18\%にるみられた（図5）.

5. 肉眼型之脈管侵襲について

静脈侵㜔、リンバ管侵㜔陽性率ともに隆起型, 隆起 型十陥凹型が高率となっている（図6）. 
6. 肉眼型とリンバ節転移について

リンパ節転移陽性率は隆起型で $50 \%$, 隆起型+陥凹 型で $40 \%$ と高く, IIc 型などの陥凹型では $11 \%$ で比較的 低率であった（図 7).

7. $\mathrm{sm}$ 浸潤程度と生存率について

5 年生存率では $\mathrm{sm}_{2} ; 97.1 \%, \mathrm{sm}_{1} ; 94 \%, \mathrm{sm}_{3} ;$ $92.5 \%$ であり，10年生存率では $\mathrm{sm}_{3}$ が87.1\%と低下し たが有意差はみられなかった（図8）.

8. 肉眼型と生存率について

5 年生存率は I, IIc, IIc +III 型が $100 \%$, IIa 型 $94.7 \%$, Ila +IIc 型 $92.8 \%$, IIc+IIa 型85.7\%であっ た. IIc+III 型は，10年生存率が85.7\%と低下したか， 生存曲線には有意差はなかった（図 9).

9. 組織型と生存率について

5 年生存率は por； $100 \%$, tub $_{2} ; 96.3 \%$, pap ; $88.8 \%$ でった。 $\mathrm{tub}_{2}$ の 10 年生存率は $89.8 \%$ に低下し たが有意差はなかった（図10）。

\section{VI. 考 察}

早期胃癌の治療成樍は極めて良好である。しかしな お $10 \%$ 前後の症例は 5 年以内に死亡している. 特に

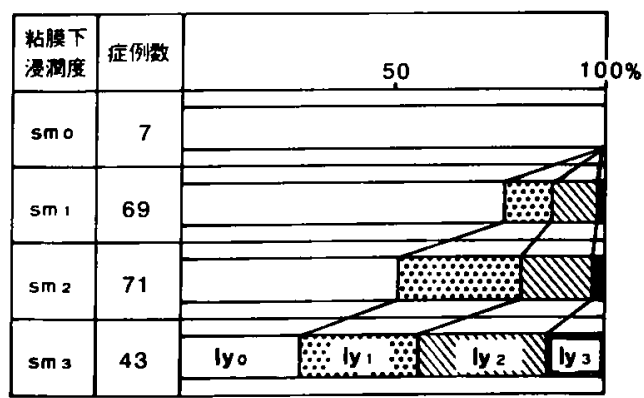

图 4 粘膜下浸洞とリンバ管侵貿

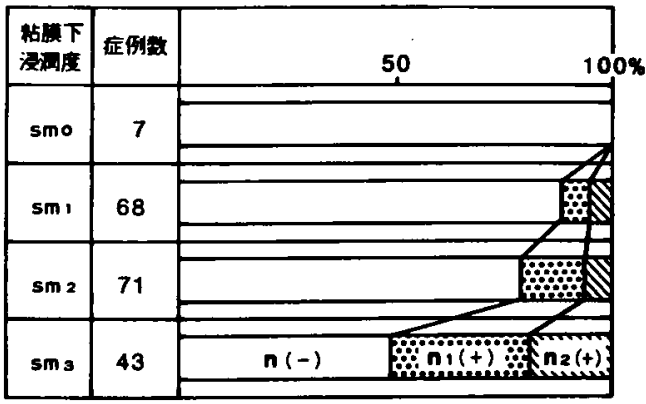

图 5 粘缕下瀑洞とリンバ節転移

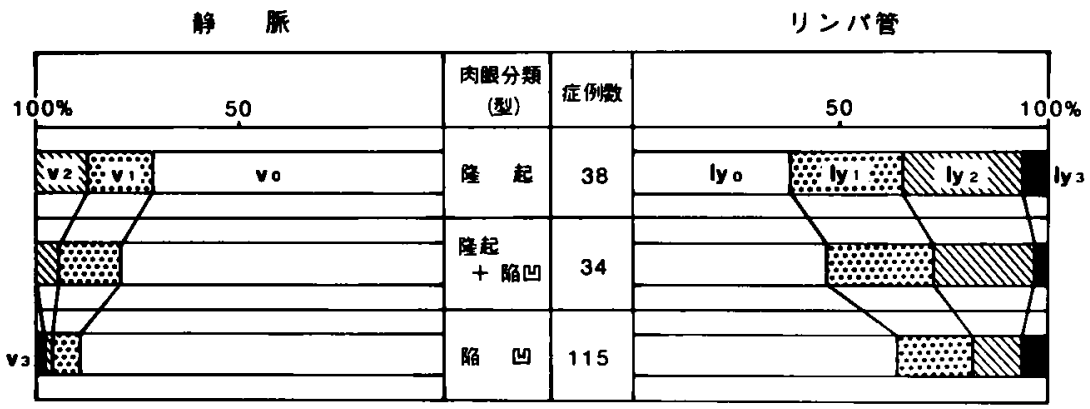

图 6 肉眼分類と脈管侵㤐

$\mathrm{sm}$ 癌においては， m癌に比して 5 年生存率がやや低 い.しかし一ロに sm 癌と言っても組織学的に浸潤程

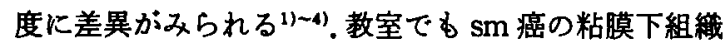
層への浸潤程度を 4 段階に分類して検討した。 $\mathrm{sm}$ 癌

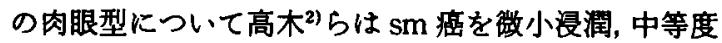
浸潤, 深部浸潤と 3 群に分類し, I, IIa+IIc 型では深部 浸潤群が多く，特に IIa+IIc 型では70\%，I 型では 52\%が深部漫潤群であったと述べている，著者らの検 討です, $\mathrm{sm}_{3}$ において I, Ila 型の隆起型と Ila + IIc 型, IIc+IIa 型などの混合型が多くみられた。 また IIc+ III, III 型の陥凹型早期癌に深部浸潤例が少ない点は早 期癌に合併する潰瘍病变に関連するるのであろらと述

\begin{tabular}{|c|c|c|c|}
\hline 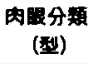 & 应体敖 & 50 & 10 \\
\hline 影 起 & 38 & $\mathbf{n}(-)$ & \\
\hline $\begin{array}{l}\text { 䧑起 } \\
+ \text { + 降凹 }\end{array}$ & 34 & & \\
\hline 俩山 & 115 & & \\
\hline
\end{tabular}

图 7 内眼分類とリンパ節転移

べられているが2), 自験例です $\mathrm{sm}_{0}, \mathrm{sm}_{1}, \mathrm{sm}_{2}$ などの曼 潤程度のものに IIc 型が多くみられた。

早期癌のリンバ節転移に関して, 鈴木5)らは全体で 


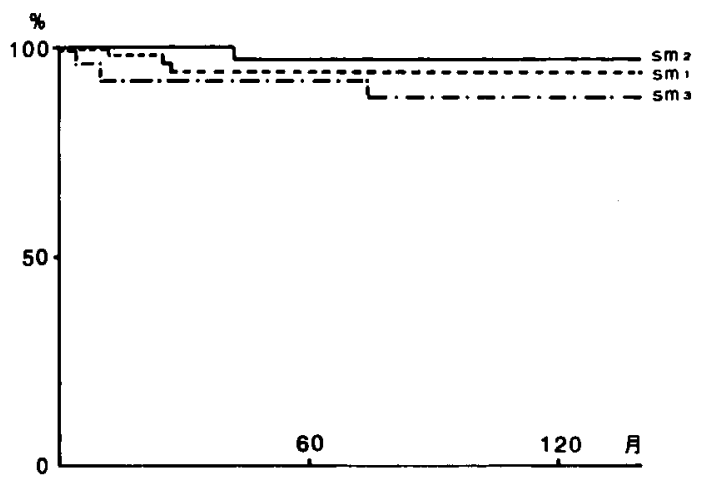

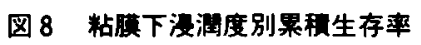

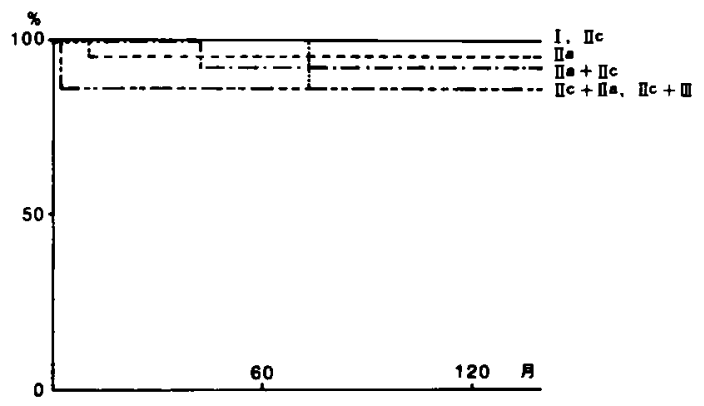

図 9 内眼分類累秘生存率

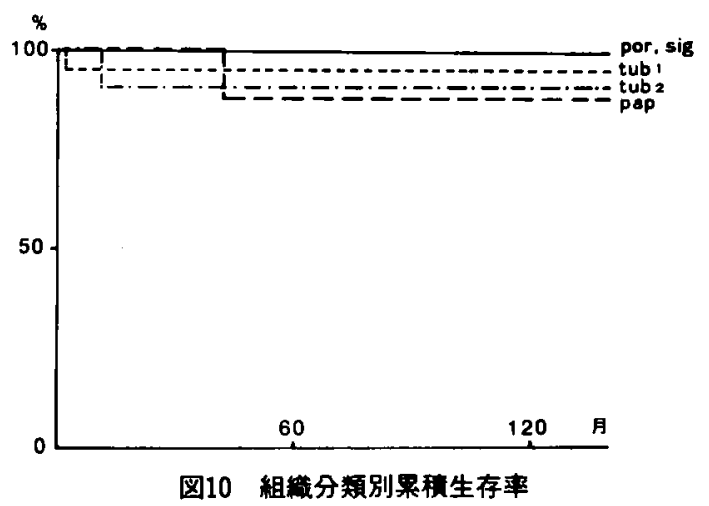

$10.3 \%, \mathrm{~m}$ 癌で $3.6 \%, \mathrm{sm}$ 癌 $16.9 \%$ あ゙あと述べてい る、しかし sm 癌を浸潤程度によって転移率を検討し ているものをみると，坂本”らの報告では $\mathrm{sm}_{1}, \mathrm{sm}_{2}$, $\mathrm{sm}_{3}$ での転移率は21.4\%, 23\%, 42\%で $\mathrm{sm}_{3}$ で高率であ

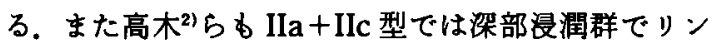
八節転移率は $41 \%$ と高いと述べている. 自験例では $\mathrm{sm}_{1} ; 13 \%, \mathrm{sm}_{2} ; 22 \%, \mathrm{sm}_{3} ; 53 \%$ あった。また肉 眼分類とリンバ節転移との関係については高木 ${ }^{2) ら は ~}$ IIa+IIc 型では深部浸潤群でリンパ節転移は $41 \%$, IIc
型では深部浸潤群では $26 \%$ と転移が多いと述べてい

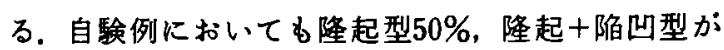
$38 \%$ ，宿凹型が $12 \% て ゙ あ る 。$ 隆起型，混合型の高度浸 潤例にリンバ節転移が高いと考えられる。このように $\mathrm{sm}$ 癌であってもその壁深達度の程度により,リンパ 節転移に著しい差異がられた。

$\mathrm{sm}$ 漫洤程度と脈管侵綮との関保については坂本” らはリンバ管侵俩陽性率は粘膜下浸潤とよく平行し， また静脈唚站の陽性率はリンバ管唚裂に比べ陽性率は 低いが，注济同梯の傾向が見られると述べている。自 駼例でも $\mathrm{sm}_{1}, \mathrm{sm}_{2}, \mathrm{sm}_{3}$ の順に陽性率が高くなり, 中で ๖リンバ管唚裝は $\mathrm{sm}_{3}$ では72\%と高く, 肉眼型との関 倸に和いては隆起型, 隆起+陌凹型が陽性率が高い。

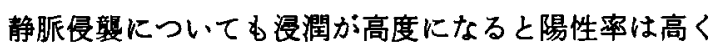
なり $\mathrm{sm}_{3}$ では $30 \%$ であり，その程度も $\mathrm{v}_{3}$ の頻度が多く なり， $\mathrm{sm}_{3}$ の癌は早期癌とい充ども進行癌に比較でき る程度の悪性度を有するといらことも出来る. $\mathrm{sm}$ 癌 の予後に関しては高末”らはIIa+IIc では深部浸潤群 でリン八節転移例に再発が認められ, 予後は不良であ ると述へている。井ロ听らは pen-A型の予後は進行癌 のそれに比較できるはどの悪性度を有すると述へてい、 る. 古賀”らも再発を来たす早期癌としては隆起型, 隆 起十陌凹型の混合型の $\mathrm{sm}$ 癌が多く，また静脈内侵襄 陽性例も多く，かつ再発様式として肝転移が多く見ら れるとのへている. 自験例の予後は, $\mathrm{sm}_{3}$ の10年生存率 $87.1 \%$ と悪くはなっているが有意差は認められなかっ た. 自験例の早期胃癌死亡例については，他病死 $57.5 \%$ にみられ, 再発例任 $\mathrm{sm}$ 癌 4 例のうち $\mathrm{sm}_{3}$ が 2 例, $\mathrm{sm}_{2}$, $\mathrm{sm}_{1}$ が各々1例ぷつみられ，その形成は腰推転移，肺転 移などがみられだ。.このよ5に早期胃癌であっても 種々の再発形式がみられ、リン八節の郭清に対する配 虙, 手術療法に加之一化学療法の必要性が覞える。教 室でも術後の組織検查の結果によって制癌剤の投与を 積極的に行らこととしている。

\section{V. 結 語}

粘膜下漫润程度を 4 段階に分頪し臨床病理学的に検 討を行い，以下のごとき結果を得た。

1） sm 癌浸潤程度が高度になると隆起型，隆起十宿 凹型の頻度が高く、リンバ節転移率, 脈管内侵㳯陽性 率は高くなり，10年生存率が低下した。

2）肉眼分類からみると，隆起型，隆起十陷凹型にリ ン八゙節転移率, 脈管内唚億陽性率が高く生存率が低下 した。 


$$
\text { 文 献 }
$$

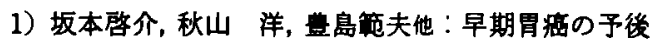
を左右する因子一特に粘膜下漫洞と予後の成保に ついて一, 手術 $26: 267-273,1972$

2）高木国夫，太田博俊：sm 㥜癌の予後を左右する因 子，胃之腸 $17: 485-495 ， 1982$

3）広田映五, 山道 昇, 板橋正幸他： sm 胃㾇の病理, 特に肉眼所見と組形態との対比，胃之腸 17 ： $497-508,1982$

4）紀藤 媇, 山村義孝：早期胃癌治療上の問題点, 癌 の臨 $32: 246-249,1986$
5）鈴木博孝，遠藤光夫，鉿木 茂他：早期胃癌におけ ろリンパ節転移の検討，日消外会誌 $17: 1517$ $-1526,1984$

6）井口 副島一彦：早期胃㴽の進展と発育形式, 外科治療 $34: 49-54,1976$

7）古賀成昌，岸本宏之，田中公晴他：早期胃癌の治原 と予後一術後死亡例を中心に一，臨と研 53 ： 77-82, 1976

8）宮本幸男, 川井忠和, 泉雄 勝：早期胃癌の治瘦成 症之臨床病理学的検討, 北蔺東医 $34: 127-132$, 1984

\title{
CLINICOPATHOLOGICAL STUDY OF ERALY GASTRIC CANCERS WITH SUBMUCOSAL INVASION
}

\author{
Yukio MIYAMOTO, Susumu OHWADA, Yoshibumi TANAHASHI, Tadakazu KAWAI \\ and Masaru IZUO \\ 2nd Department of Surgery, Gunma University School of Medicine \\ (Director: Prof. Masaru IZUO)
}

Early gastic cancers with submucosal invasion were divided into the following four subtypes: 1) cancerous invasion mucosal layers and ulcer scars $(\mathrm{sm} 0), 2$ ) slightly infiltrative type wit minute and partial submucosal invasion ( $\mathrm{sm} 1), 3$ ) moderately infiltrative type, and intermediated type with invasion down to the mid-submucosal layer (sm2), 4) deep infiltrative type with deep and massive invasion almost to the proper muslce (sm3). One hundred and ninety were investigated with regard to clinicopathological factors.

1) The deep infiltrative type was more frequent in the protruded, elevated, and depressive types than in the other types of early gastric cancer.

2) The rates of lymphnode metastasis and of lymphangitic and blood vessel invasion increased in the deep infiltrative type.

3) The survival rate in this type at ten years was lower than in the other subtypes. 